\title{
"IMPACT ASSESSMENTS IN VOLCANIC AREAS - THE VESUVIUS AND CAMPI FLEGREI CASES STUDIES,
}

\author{
Giulio Zuccaro*,1,2 and Daniela De Gregorio ${ }^{1}$ \\ (1) PLINIVS - LUPT Study Centre, University of Naples Federico II Palermo, Palermo, Italy \\ (2) Department of Structures for Engineering and Architecture, University of Naples Federico II, Napoli, Italy
}

Article history

Receveid June 21, 2018; accepted February 19, 2019.

Subject classification:

Volcanic risk; Volcanic vulnerability; Emergency planning; Vesuvius; Campi Flegrei.

\begin{abstract}
The emergency planning of areas subjected to volcanic risk requires the evaluation of impact induced on different element exposed (people, buildings, infrastructures, economy, etc.) by different volcanic phenomena (precursor earthquakes, ash fall, pyroclastic flows, lahars, tsunami, ballistics, landslides, etc.).

In this paper, we describe the methodology developed at PLINIVS Study Centre (University of Naples Federico II, Italy), Centre of Competence of the Italian Civil Protection, in the framework of volcanic risk assessment, concerning the active volcanoes of Campania Region. The approach is based on probabilistic analyses of risk and impact scenarios. It allows quantifying the potential losses consequent to possible volcanic eruptions. The results are strongly dependent on the hypothesis assumed and on the parameters used as inputs, providing impact scenarios with a probabilistic estimation and uncertainty treatment. The results constitute a useful tool for emergency planners and decision makers in the evaluation of the resources needed to improve the preparedness measures and to implement technically feasible and cost-effective mitigation measures on buildings and infrastructures. The scope is to reduce the expected damage and to ensure the practicability of the emergency plan, e.g. by the seismic retrofitting of vulnerable buildings along the escape routes identified in the evacuation plan, which might fail due to the presence of debris from buildings collapsed, because of precursor earthquakes, which can affect the practicability of roads.

The paper is focused on the relevant applications performed by PLINIVS simulation model for the preparation and updating of the emergency plan for Vesuvius and Campi Flegrei areas.
\end{abstract}

\section{INTRODUCTION}

Two active explosive volcanic systems, SommaVesuvius and Campi Flegrei, are located inside the Neapolitan metropolitan area. The hazards which characterizes the volcanoes [Neri et al., 2008; Neri et al., 2015; Selva et al., 2014; Macedonio et al., 2016; Bevilacqua et al., 2017], the high exposure of urban area, which counts about three million people and the high vulnerability of the built environment, character- ize this area as one with the highest volcanic risk in the word [Baxter et al., 2008; Zuccaro et al., 2008]. The need of the territorial planning and the identification of the management strategies of possible emergencies produced, during the years, an increasing interest in the assessment of possible damages caused by eruptions in this area.

The aim of this paper is to describe some probabilistic methodologies for volcanic impact assessment produced by the volcanic eruptions, in order to address the 
planning strategies, the management of the emergency and the possible measures of risk mitigation [Zuccaro and De Gregorio, 2016].

Among the phenomena produced by a volcanic eruption a particular interest is addressed to earthquakes, ash fall and pyroclastic flows.

The last one is the most devastating phenomenon and the unique mitigation strategy is the preventive evacuation of people from the exposed area. So, the interest of the planner in the assessment of the damages caused by pyroclastic flows is reduced in favor of the assessment of hazard and the prevision "run out" of the currents.

Therefore, in this article the assessment of the damage to the buildings and to the road network caused by earthquakes and ash falls is specifically addressed, whereas a possible methodology to assess the damages caused by pyroclastic flows is only mentioned.

\section{RISK AND SCENARIO ANALYSES}

An efficient management of the effects due to volcanic eruptions on urban regions need their preliminary assessment on the territory. In this perspective, two different types of assessment are recognized according to different aims, one based on the risk assessment and the other one based on the scenario assessment.

The "risk" is the probability to reach a predetermined level of damage on given element exposed (people, buildings, infrastructures, economy, etc.) caused by volcanic events occurring in a given period of time and in a certain geographical area. The risk should be considered as a cumulative assessment, related to the potential total damage generated by all volcanic events that can occur in a given area in a predetermined time period.

The "scenario", instead, represents the probabilistic distribution of the damage, in a given geographical area, caused by a single volcanic event of intensity "i" (chosen as scenario of reference), with assigned probability of occurrence (reference scenario),

In both analyses, three aleatory variables (hazard, exposure and vulnerability) must be considered [Unesco, 1972; Fournier d'Albe, 1979], according to the convolution (1).

$$
\begin{gathered}
\text { Risk [Scenario] = Hazard Scenario [Hazard] } \\
x \text { Exposure } x \text { Vulnerability }
\end{gathered}
$$

The "hazard scenario" is the probability of occurrence of all the possible volcanic events [of each single "hazard" event] in a specific area during a specific time.

The "exposure" is the qualitative and quantitative geographic distribution of the different elements at risk (population, buildings, infrastructures, activities and facilities) which characterize the examined area, whose conditions and/or functionality could be damaged, modified and destroyed because of the occurrence of the volcanic events.

The "vulnerability" is the sensitivity of an exposed element to a given volcanic event. It can be assessed as the probability that an exposed element reaches a given level of damage, according to an opportune measurement scale, under the effects of a natural event of assigned intensity.

Specifying the relation (1), the risk to reach a certain level of damage " 1 " can be determined through the relation (2).

$$
\operatorname{Risk}_{l}=\int_{m} q_{m}\left[\int_{i}\left(H_{s i}\right) \cdot\left(V_{l, i, m}\right)\right]
$$

where: $H_{s i}$ is the probability of occurrence of overall hazard scenarios with severity "i" during a specific time and in a specific area; $V_{l, i, m}$ is the probability to achieve an assigned damage level "l" by a specific category ' $m$ ' (vulnerability class) of elements at risk; $q_{m}$ is the percentage of exposed elements of category ' $m$ '.

The scenario to achieve an assigned damage level ' $\mathrm{l}$ ' under the effect of a single volcanic event with intensity "i", instead, can be determined through the relation (3).

$$
\text { Scenario }_{l, i}=\int_{m} q_{m}\left[\left(H_{i}\right) \cdot\left(V_{l, i, m}\right)\right]
$$

In the emergency planning, either analysis can be used, according to different pursuing aims.

The risk analysis allows comparative assessment of areas to define subordinated strategies of intervention (for example, priority of evacuation or damage mitigation interventions).

The scenario analyses are able to define the territorial extension of the impact, so they are useful to quantify the necessary resources in the emergency planning and to plan the operative intervention organization.

In this paper, we show some examples of application of risk and scenario analyses. For the risk aspect, the evaluation of the risk maps due to ash falls in order to define the areas to evacuate in pre-eruptive phase is illustrated. For the scenario aspect, instead, the importance of seismic scenario maps is shown, in order to assess the critical aspects connected to the practicability of the escape routes from the areas to be evacuated. 


\section{VULNERABILITY AND EXPOSURE}

In this section, some methodologies for the assessment of vulnerability and exposure are presented.

Vulnerability and exposure represent strictly connected factors. For each category of exposed elements, the assessment of vulnerability due to a given natural event must be combined with "a qualitative and quantitative analysis of the exposed element" (exposure), in order to identify the time-spatial distribution of typological classes of exposed element, defined as 'vulnerability classes'. Each of them represents a group of elements having the same characteristics, which presents the similar behavior (vulnerability) in face of a given phenomenon.

\subsection{VULNERABILITY}

\subsubsection{BUILDINGS}

The vulnerability of a building, considered as a single structural unit, is the probability that the system (entire building), the sub-system (walls, cornices, roofs, etc.), or the components of the system (beams, pillars, windows, doors, etc.) is damaged owing to a defined action (natural event).

The definition of vulnerability suggests the necessity to identify unambiguously the level of the damage of the exposed buildings due to the natural event. In Table 1, a scale of possible damage of the building is defined. The propensity of a building to be subjected to damages is function of its constitutive elements. The resistance and technological aspects of structural elements (walls, beams, pillars, slabs, roofs, etc.) and no structural elements (infills, openings, protection panels, etc.) strongly influence the building vulnerability [Baxter at al., 2005; Zuccaro and De Gregorio, 2013; Zuccaro et al., 2014; Mavrouli et al., 2014]. In particular, the vulnerability of a building in face of a volcanic phenomenon (earthquake, pyroclastic flow, ash fall, lahar, etc.) can be evaluated through the "vulnerability curves'. For an assigned vulnerability class ${ }^{1}$, the curves express the probability to exceed a certain level of damage depending on the measurement of hazard parameters, which can be the peak ground acceleration, the spectral intensity, the macro seismic inten-

'VULNERABILITY CLASSES ARE DEFINED AS A SET OF BUILDINGS THAT HAVE A SIMILAR BEHAVIOUR IN FACE OF AN ASSIGNED VOLCANIC EVENT, IN FUNCTION OF A GIVEN COMBINATION OF TYPOLOGICAL AND STRUCTURAL CHARACTERISTICS. sity, the dynamic pressure of a flow (landslide, flood, pyroclastic flow, etc.), the ash load, etc.

The vulnerability curves can be represented through three different approaches: observational method, mechanical method and hybrid method, according to the available data.

The observational method provides the vulnerability curves through the statistical analyses of the damages observed in past events considering a huge sample of buildings. The mechanical method obtains the vulnerability curves through the statistical elaboration of the results of mechanical analyses (non-linear) considering a random sample of models which represents the built environment of the considered area (for example, generated with Montecarlo's simulation) and exposed to a representative set of events (hazard).

In the hybrid method the vulnerability curves are obtained combining the mechanical and observational analyses of the damages produced by past events.

For example, Figures 1, 2 and 3 represent the vulnerability curves of the Vesuvius buildings towards earthquake, ash fall and pyroclastic flows respectively.

The curves of Figure 1 have been obtained for buildings classified according to the European macroseismic scale (EMS'98), through an observational method based on statistical analyses of the distribution of the detected damages, as a result of past earthquakes [Zuccaro, 2004; Zuccaro et al., 2008; Zuccaro and De Gregorio, 2013].

The curves in Figure 2 are determined through a hybrid statistical approach, based on numerical analyses of the limit state of collapse and on experimental tests [Spence et al., 2004b; Zuccaro et al., 2008]. They refer to the typological classes indicated in Table 2, defined through the examination of more of 19,000 roofs in the Neapolitan area [Spence et al., 2005].

The curves of Figure 3 are determined through mechanical analyses of the limit states, by varying the typological characteristics of vertical structures, slabs and the building's height [Zuccaro et al., 2000, 2008; Spence et al., 2004 a,b]. They refer to the typological classes defined in Table 3. Considering the pyroclastic flows, it is important to specify that the damages to the buildings are not caused by the vulnerability of structural elements only, but also by the resistance of non-structural elements, such as doors and openings and infill panels, whose crisis allows gas and ash of high temperature to enter; they can actually cause fire, in addition to the risk for people's life. For these reasons, 
D0

D1

D2

Moderate Damage

D3

D4

Partial Collapse

D5

Collapse
Negligible damage to the structural elements

Negligible damage to the infill panels

Breakage of large or weak openings

Moderate damage to structural elements

Moderate damage to weak infill panels

Breakage of medium-resistant openings

Severe damage to structural elements

Severe damage to weak infill. In a few cases, total collapse of the infill panels

Break of strong openings

Partial collapse of structural elements

Breaking of strong infill panels

Total Collapse

TABLE 1. Example of damage scale of buildings.

some experimental tests on the collapse of the non-structural elements under the effects of horizontal pressures have been carried out [Spence et al., 2004b]. The results are synthetized in Table 4. A similar methodology was adopted for the assessment of building's vulnerability under the effect of a horizontal pressure caused by landslides and lahars [Zuccaro and De Gregorio, 2013; Mavrouli et al., 2013].
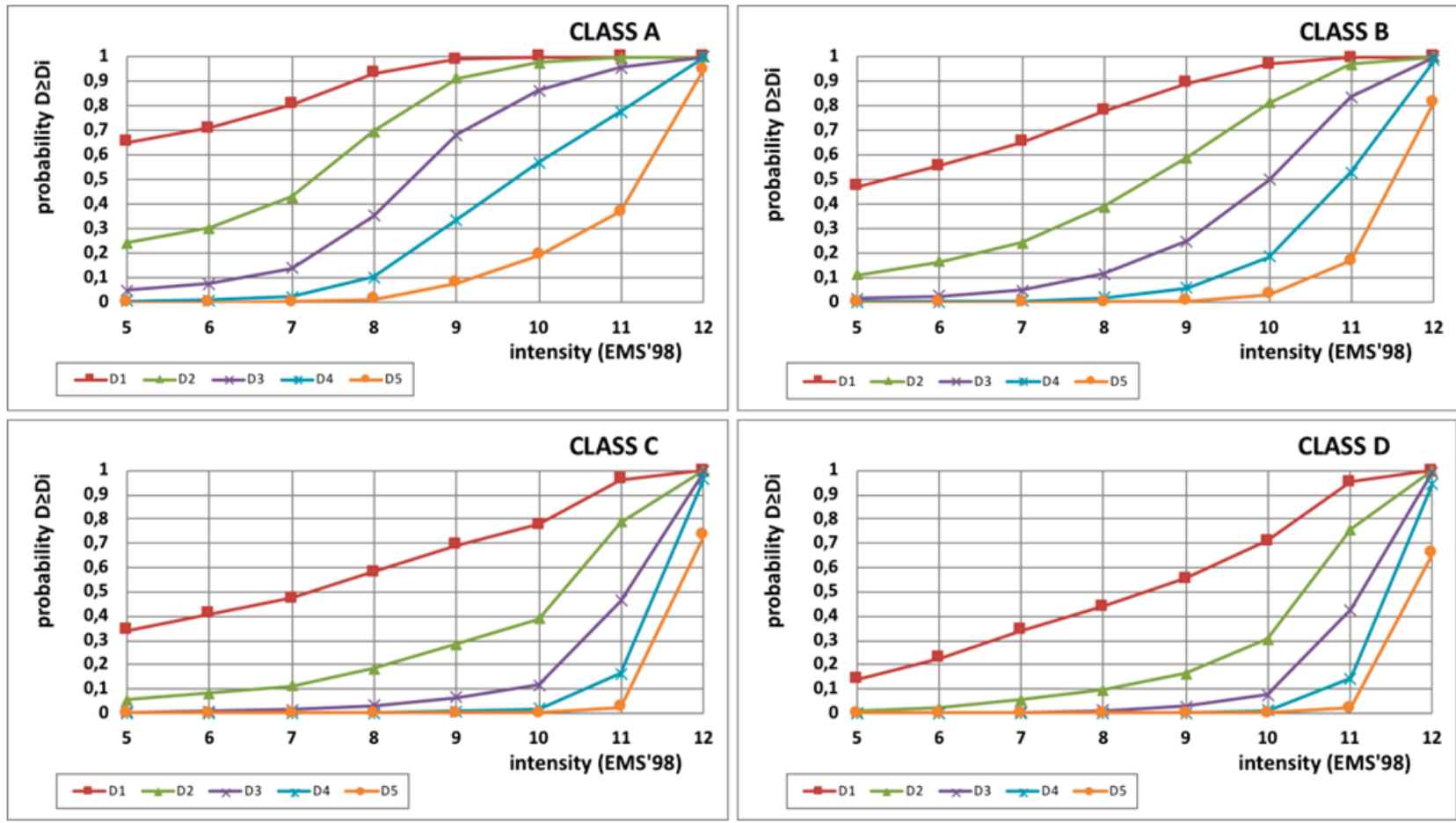

FUGURE 1. Vulnerability curves of buildings (classified according to EMS'98) in relation to a seismic event [Zuccaro, 2004; Zuccaro et al., 2008; Zuccaro and De Gregorio, 2013]. 


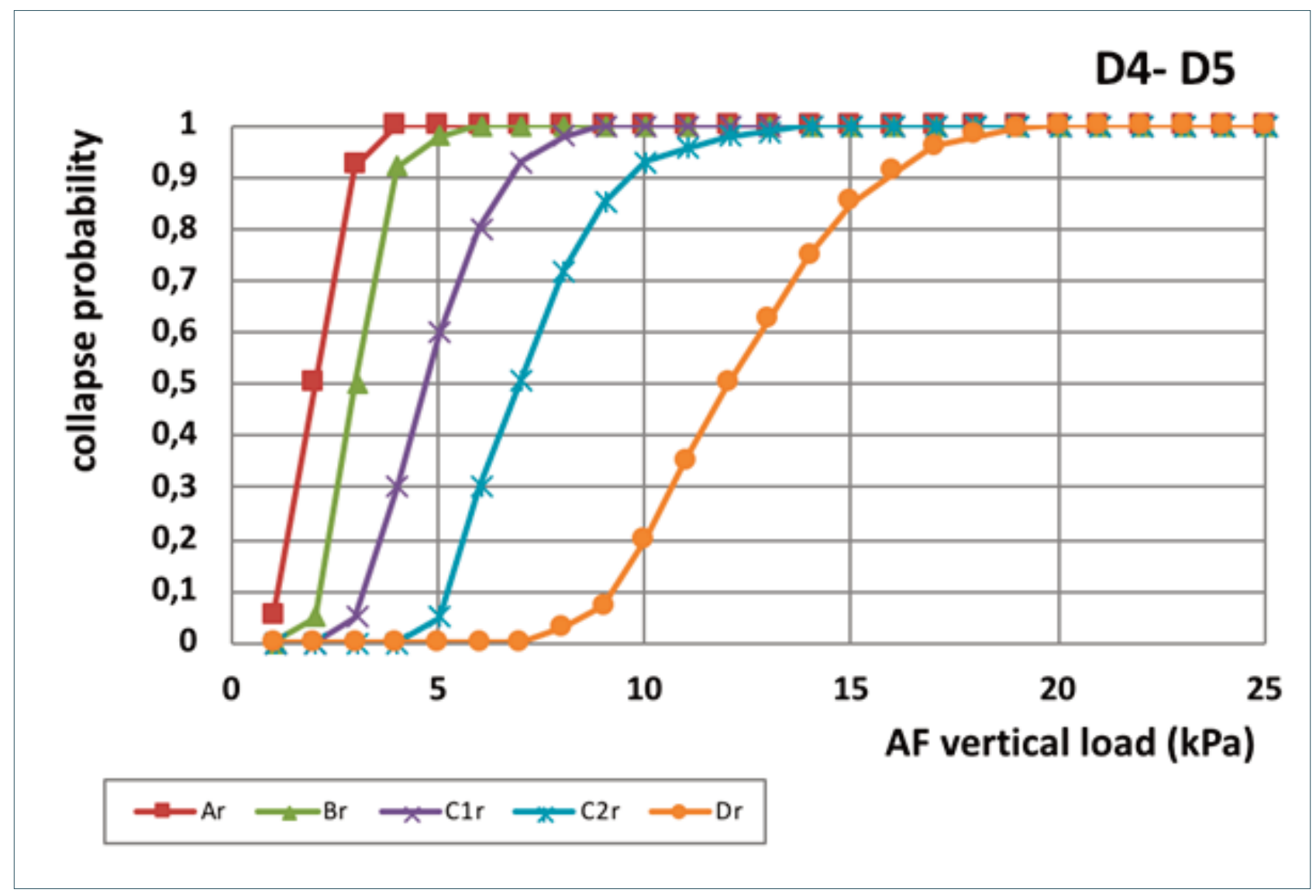

FUGURE 2. Roof vulnerability curves (classified in Table 2) with regard to ash fall loads. [Spence et al., 2004b; Spence et al., 2005; Zuccaro et al., 2008]. See also Figure 4.

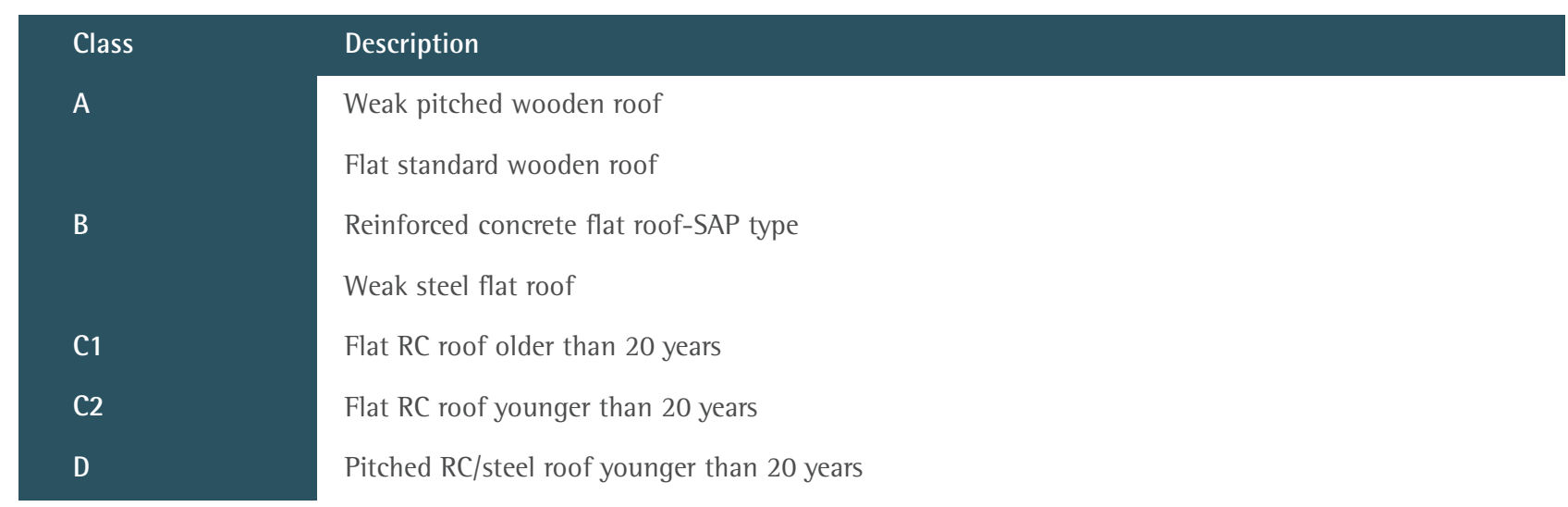

TABLE 2. Typological classification of Vesuvian and Phlegrean roofs [Spence et al., 2004b; Spence et al., 2005; Zuccaro et al., 2008].

\subsubsection{ROAD NETWORK}

In common risk analyses, the vulnerability of road network (and railways) towards a natural event is correlated to its impracticability, which could affect the circulation more or less seriously and also be an obstacle for the operations of emergency and evacuation.

In the case of a seismic event, for an assigned value of hazard, the probability of interruption of road network depends on the vulnerability of the facing build- ings (Figure 5), particularly, on the number of buildings affected by partial or total collapse, through the relation (4).

$$
P_{i}=1-1 / e^{N c}
$$

where: $P \mathrm{i}$ is the probability of interruption of the road link (link = road section between two road intersections) and NC is the number of buildings affected by partial or 

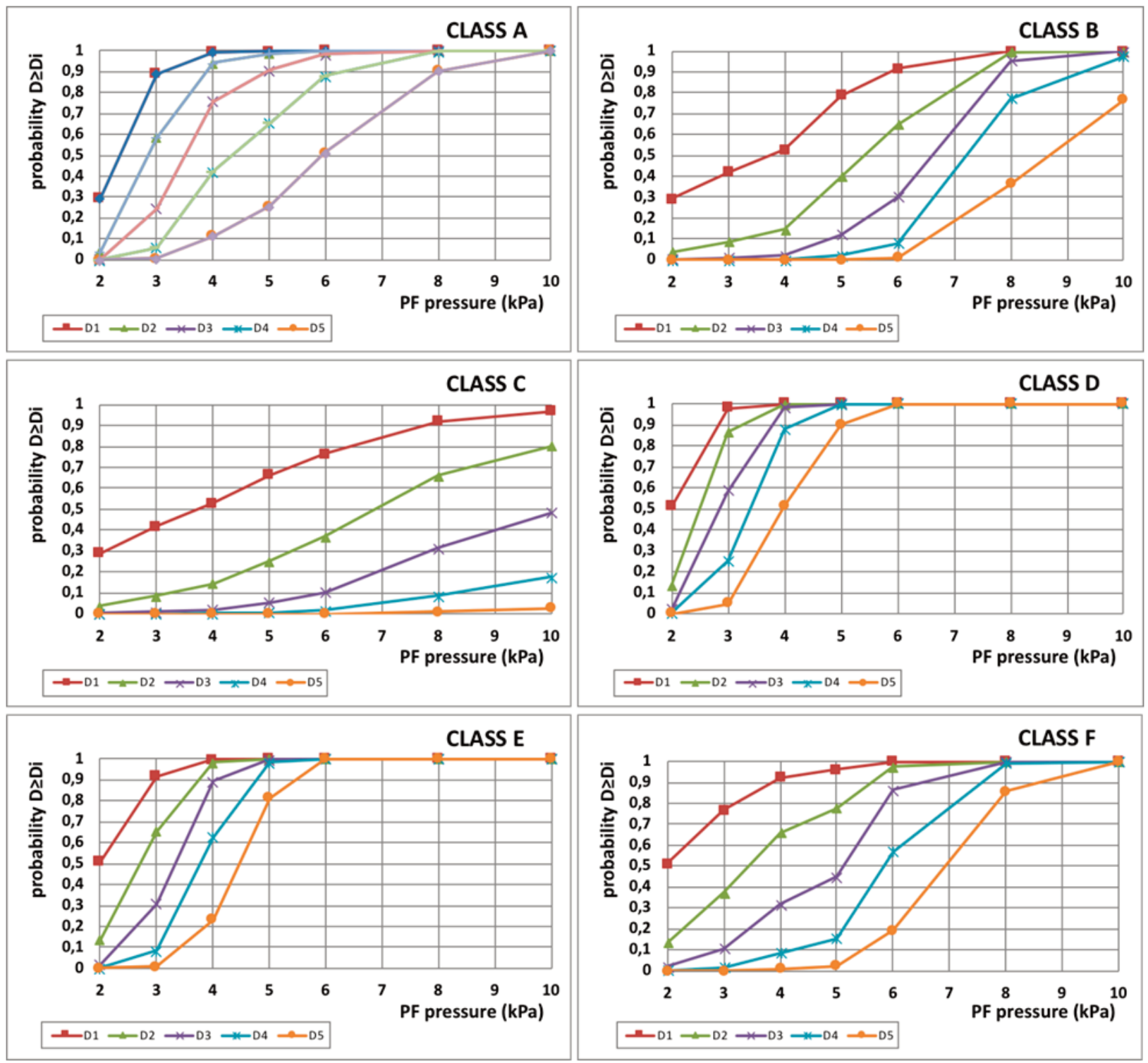

FUGURE 3. Vulnerability curves of buildings (classified in Table 3) with regard to pyroclastic flows [Spence et al., 2004b; Spence et al., 2005; Zuccaro et al., 2008].

total collapse per link, whose ruins can occupy the road network [Zuccaro and Cacace, 2010].

In case of volcanic eruptions, the probability of road interruption can be evaluated according to the temporary distribution of the different generated phenomena. For example, in the pre-eruptive phase and in an area near to the vent, precursory earthquakes can produce roads interruption due to the partial or total collapse of facing buildings. In the eruptive phase, the ash fall could cause road interruptions even many kilometers away from the vent. An ash thickness about 1-3 $\mathrm{mm}$ is able to reduce the road visibility, to make dangerous the road slippery and to cause several damages to vehicles, thus it can be necessary to close the roads temporarily.
In addition, the eventual presence of pyroclastic flows and lahars on the roads can cause the traffic disruption [Wilson et al., 2014].

\subsection{EXPOSURE}

\subsubsection{BUILDINGS}

The exposure assessment in the examined area is based on statistical analyses, which consider the percentage distribution of different vulnerability classes of the buildings according to their behavior towards a natural event.

In relation to earthquakes, the macro-seismic European scale (EMS '98) defines six vulnerability classes 

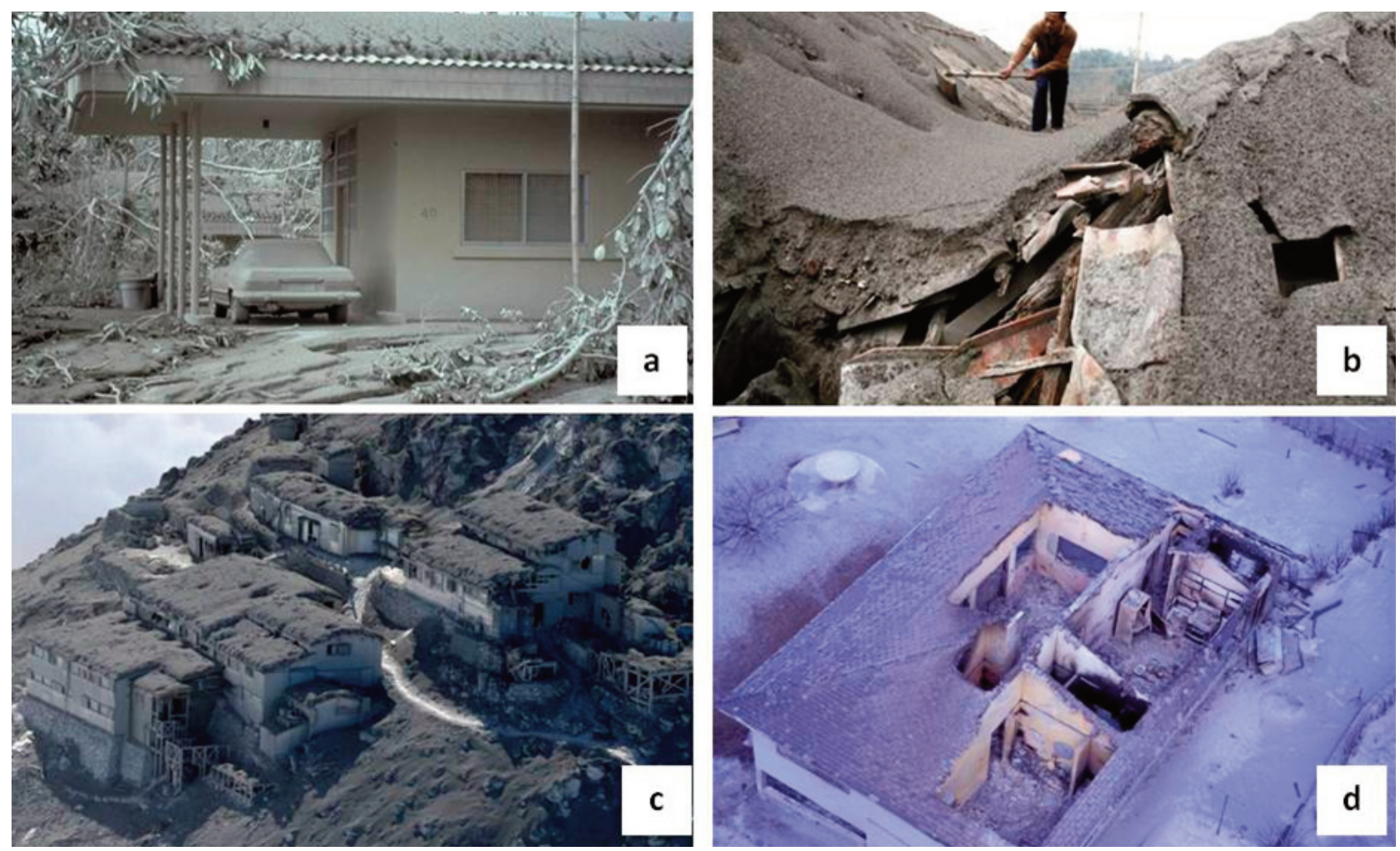

FUGURE 4. Roof vulnerability to ash fall: a) 1991 eruption of Mount Pinatubo, Philippines (www.volcanoes.usgs.gov); b) 2014 eruption of Mount Kelud, Indonesia (AFP photo); c) 2014 Mount Ontake eruption, Japan (Photo / Kyodo News); d) 1997 eruption of the Soufiere Hills, Montserrat, UK.

(A, B, C, D, E, F) based on the buildings vertical structure. This classification can be used with poor and easily reachable information; on the other hand, it is

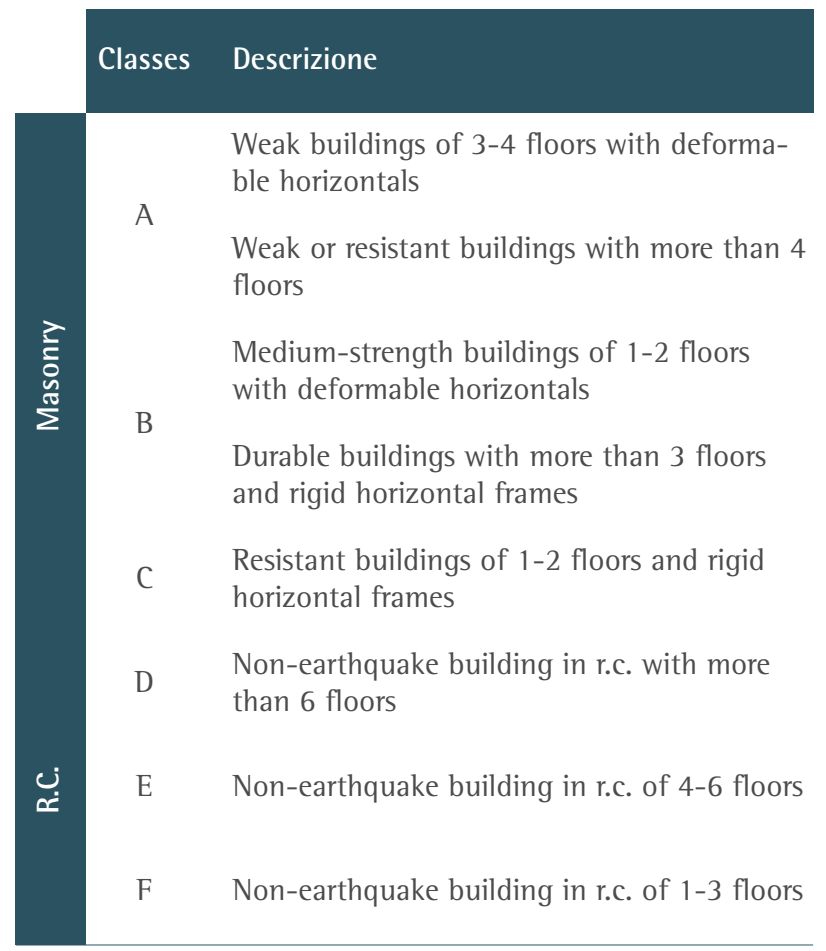

TABLE 3. Typological classification of the Vesuvian and Phlegraean buildings. [Spence et al., 2004b; Spence et al., 2005; Zuccaro et al., 2008]. characterized by huge uncertainties because is neglects the others information which characterize the seismic behavior of a building, such as the horizontal structure, roof, regularity, age, etc. Current scientific debates aim to reduce these uncertainties through the assignment of the vulnerability classes considering additional structural and typological factors [Zuccaro et al, 2008; Michel and Sira, 2012; CAR, 2103]. Referring to the other natural events, the vulnerability classes are classified differently than those used for the seismic events.

In the case of volcanic eruptions, characterized by a plurality of events (precursory earthquakes, ash fall, pyroclastic flows, lahars, landslides, tsunami), different vulnerability elements have to analyzed in addition to those considered in the seismic analysis (vertical structure, horizontal structure, regularity, etc.). For example, features related to structure and geometry of roofs, which are directly hit by ash fall (Table 2 and Figure 4), must be considered, as well as the characteristics of infill panels and openings must be considered for the facades exposed to pyroclastic flows, lahars and tsunami [Spence et al., 2004a e b; Baxter, 1990; Zuccaro et al., 2008; Petrazzuoli and Zuccaro, 2004; Zuccaro et al, 2012].

When the vulnerability classes are defined, a cogni- 
Elements

Ordinary glass plates

Aluminium windows in poor condition

Aluminium windows in good condition

Old wooden doors

Yellow tuff masonry $(<40 \mathrm{~cm})$

Old wooden windows

Perforated brick filling without openings

Yellow tuff masonry (length $4 \mathrm{~m}$, thickness $40 \mathrm{~cm}$ )

Perforated brick filling with opening

Yellow tuff masonry (length $4 \mathrm{~m}$, thickness $60 \mathrm{~cm}$ )

Masonry in volcanic stone (length $4 \mathrm{~m}$; thickness $60 \mathrm{~cm}$ )
Collapse load [kPa]

$<1.5$

1.5

3.0

3.5

$4.2-7.4$

5.0

5.5

$6.8-9$

$7.6-8.9$

$10-13$

$20-26$

TABLE 4. Horizontal collapse pressures of non-structural elements [Spence et al., 2004b].

tive campaign of the buildings of the area has to be carried out in order to assign for each of them a vulnerability class.

According to the different knowledge of the building the UMR, the vulnerability classes can be defined through opportune statistical correlation between buildings data which are contained in the database ISTAT (from "Censimento generale della
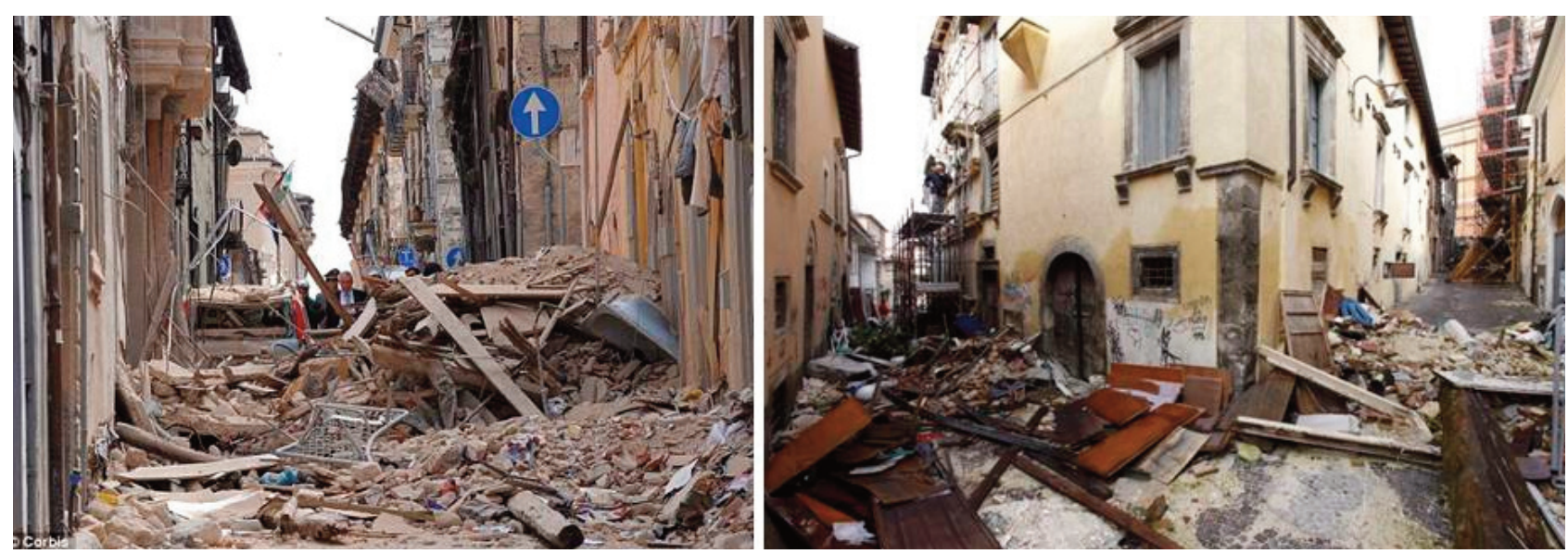

FUGURE 5. Interruption of road sections due to the seismic vulnerability of the buildings facing the street (L'Aquila, 2009).

fabric, the possible techniques are the following [Zuccaro et al., 2012]:

a) In the case of all the buildings data are available in the Minimum Geographical Reference Unit (UMR), the vulnerability class can be defined directly, according to the known elements [Zuccaro and Cacace, 2015].

b) In the case of no buildings data are available in popolazione e delle abitazioni”) and the buildings characteristics obtained from a relief of areas with the same characteristics of UMR, often adjacent [Cacace et al., 2018].

c) In the case of only a partial number of buildings data are available in the UMR, the vulnerability classes can be defined through a weighted average between the classes obtained through the direct 


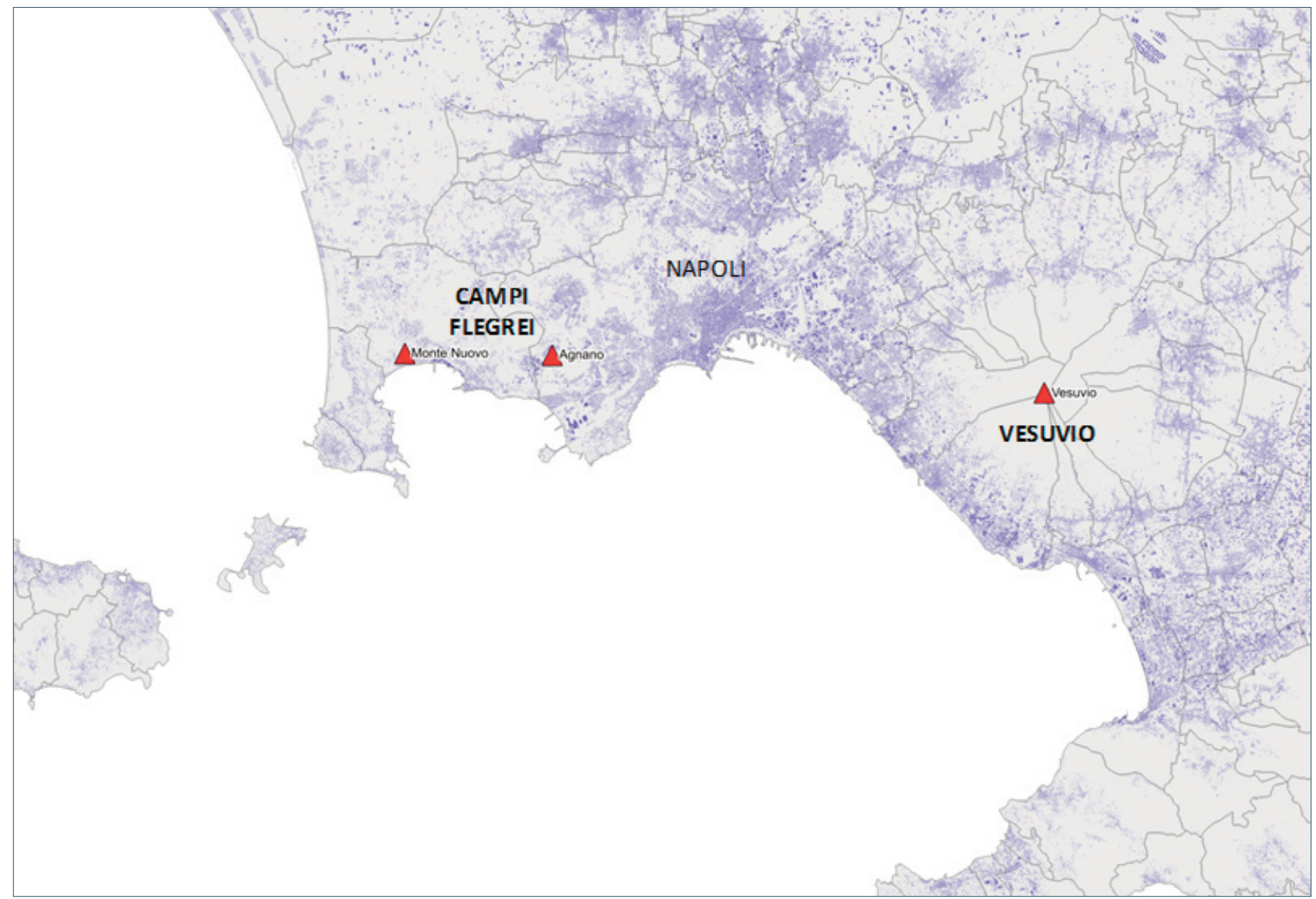

FUGURE 6. Location of the volcanic systems of Vesuvius and Campi Flegrei. The triangles indicate the probable location of the eruptive vents.

application (EMS '98, etc.) for the buildings with known characteristics and those deduced from ISTAT data, proportionally to the percentage of completeness of the relief.

\subsubsection{ROAD NETWORK}

The assessment of the exposure of road network consists of the identification of roads (called "link"), included between two road intersection (or "nodes"), classified for type (motorway, main suburban roads, secondary suburban roads, urban roads, urban streets, local roads, cycle routes), road dimension and sense of route.

\section{RISK ANALYSES FOR THE IDENTIFICATION OF THE AREAS TO BE EVACUATED}

The Emergency Plans, developed by the National Department of Civil Protection with the help of the scientific competences and local administrations, represent a useful tool for the mitigation of volcanic risk, which starts with the volcanic hazard assessment of volcano (choosing an event as reference), and is completed with the exposure/ vulnerability assessment of the elements hit by the eruptive phenomena. For Vesuvius and Campi Flegrei (Figure 6), explosive eruptions are expected [Orsi et al., 2004; Orsi et al., 2009; Cioni et al., 2008]. These are characterized by the formation of a sustained eruptive column, with the falling of large size volcanic fragments and stone near to the vent and of small particles (lapilli and ash) even several tens of kilometers away in the downwind areas; then the column collapses with the formation of pyroclastic flows which would descend along the volcano slopes. For Campi Flegrei, where there is not a central vent as Vesuvius, the area where an eruptive vent might open is rather wide [Selva et al., 2011; Bevilacqua et al., 2015; Bevilacqua et al., 2017; Tadini et al., 2017; Neri et al., 2015]; besides, it is necessary to consider that, unlike Vesuvius, the city of Naples is situated downwind with respect to Campi Flegrei, so it would be affected by ash fallout.

The Emergency Plans developed for the two Neapolitan volcanoes, consider the individuation of different areas, defined as "red zone", for which a preventive 


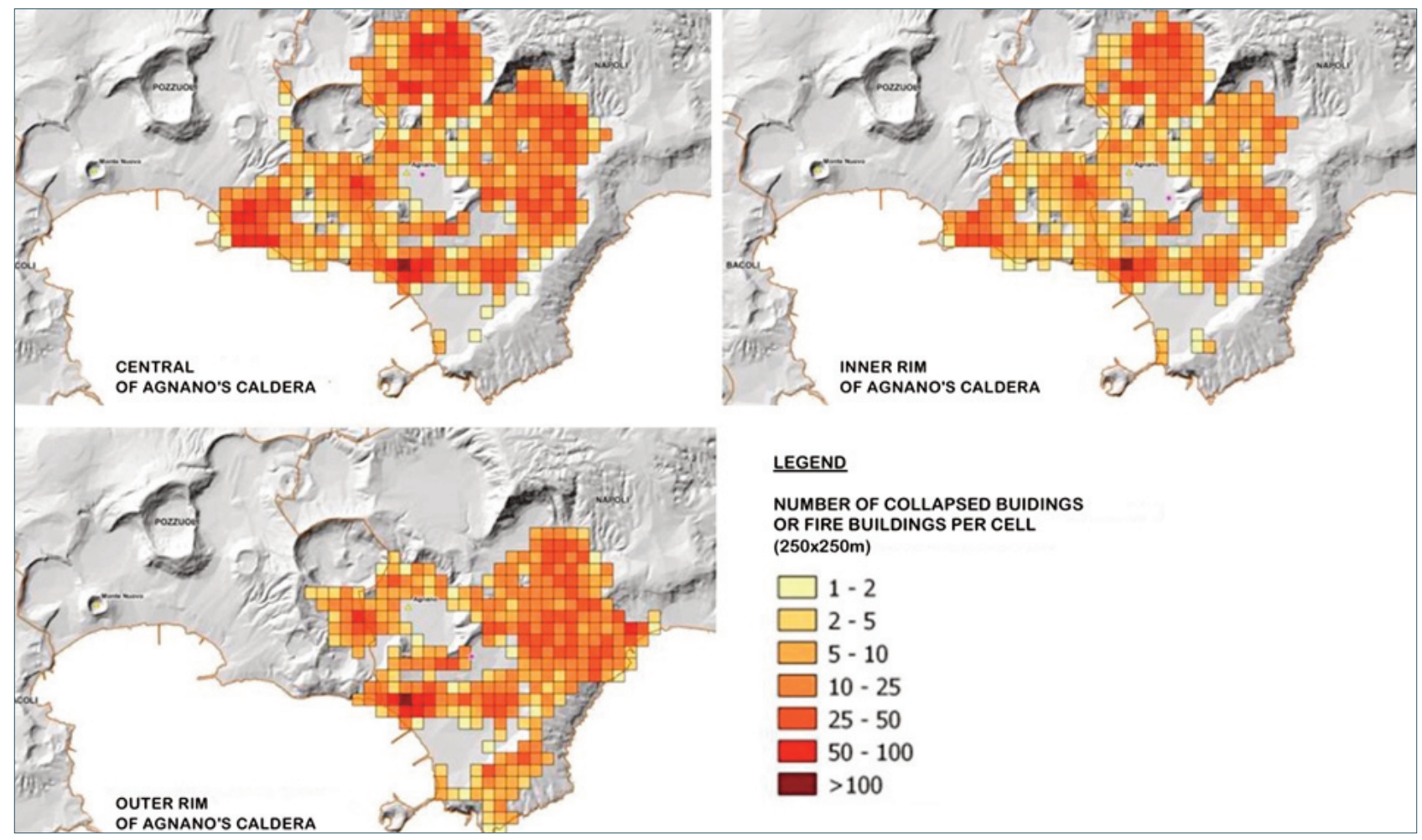

FUGURE 7. Campi Flegrei. Damage to buildings (collapsed or burned) due to the pyroclastic flows assessed with reference to Plinian phase of the eruption of Agnano Monte Spina (AMS) of 4100 years ago.

evacuation is foreseen, and "yellow zone", potentially affected by post-eruption evacuation.

\subsection{DAMAGES INDUCED BY PYROCLASTIC FLOWS}

The Emergency Plans identify the red zone as the potential area flooded by pyroclastic flows. These consist of gas clouds charged with hot vapor and particles, which are able to flow slope down up to reach considerable distances from the point of emission, a speed that can easily exceed $100 \mathrm{~km} / \mathrm{h}(\sim 30 \mathrm{~m} / \mathrm{s})$. Their temperatures may be higher than $500^{\circ} \mathrm{C}$ and they cause serious respiratory problems, caused by particles dispersed in the air, and damages to heart and brain, due to high temperatures. Plans assume that the survival of people who are outdoors in the areas reached by pyroclastic flows is very unlikely. The odds of "casualties' among the occupants of a building, however, can be assumed proportional to the collapse of the elements (structural or not) that constitute the building, especially the openings, which guarantee or not the sealing of the building envelope in relation to the pyroclastic flows [Baxter et al., 1998; Spence et al., 2005; Baxter et al., 2005; Neri et al., 2014; Cole at al., 2015]. Analyses of the damage expected from pyroclastic flows in the Vesuvian and Flegrean areas have highlighted the particular vulnerability of the built with respect to the dynamic pressure of the flows. For example, for pyroclastic flows generated by the Plinian phase of the eruption of Agnano - Monte Spina (AMS) of 4100 years ago [Esposti Ongaro et al., 2007; Esposti Ongaro et al., 2008; Neri et al., 2017], the sum of buildings collapsed due to the dynamic pressure and of those burned (corresponding to those with broken windows reached by a flow temperature greater than or equal to $250^{\circ} \mathrm{C}$ ) exceeds $90 \%$ of the invested buildings (Figure 7), regardless of the position of the eruptive vent (central, on the edge inside or outside the caldera of Agnano). It is clear that the only defense for the population is its evacuation from the area at greatest risk, the one that can be invaded by pyroclastic flows, before the beginning of the eruption. Based on the analysis of the precursory phenomena monitored by its surveillance system, the INGV Vesuvius Observatory should release an alarm for impending eruption and the evacuation plan should be activated.

\subsection{DAMAGES INDUCED BY ASH FALL}

Most recent updates of the Vesuvius Emergency Plan have considered that the load of ash fallout deposits in areas not affected by pyroclastic flows, can produce a number of collapses that makes necessary also to evac- 


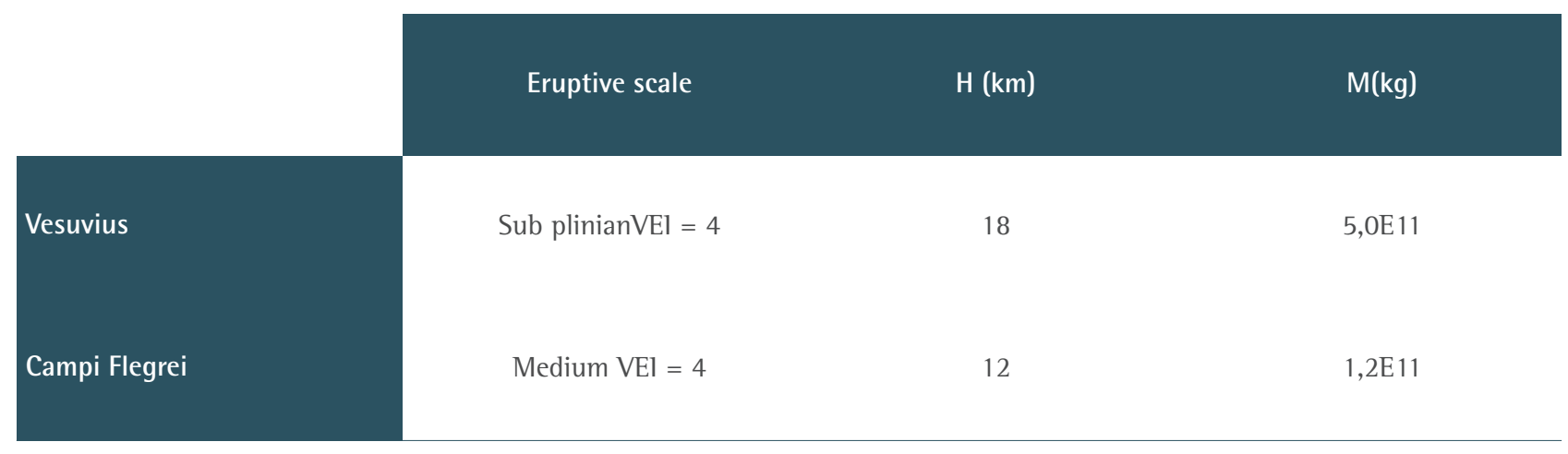

TABLE 5. Reference eruptions for the emergency plans of Vesuvius and Campi Flegrei. $\mathrm{H}$ is the height of the eruptive column, M is the total erupted mass.

uate these areas during the pre-eruptive phase. For this reason, the "red zone" has been extended, based on ash fall risk analyses linked to the reference eruptions, chosen for the drafting of emergency plans for Vesuvius and Campi Flegrei (Table 5).

The hazard estimates are carried out through simulations of the ash and lapilli dispersion, considering the variability of the wind and, for the Phlegrean Fields, the positions of the eruptive vent [Mastrolorenzo et al., 2008; Costa et al., 2009; Selva et al., 2010; Macedonio et al., 2016; Selva et al., 2017]. The results are produced in the form of families of conditional hazard curves, showing the probability of excess of 27 load thresholds $(50,100,200,300, \ldots, 3000 \mathrm{~kg} / \mathrm{m} 2)$, conditioned by the occurrence of the reference eruptive event. The expected damage to buildings due to fallout deposits generated by a sub-Plinian Vesuvius eruption, has been assessed on the basis of the combination of hazard, exposure and vulnerability data, indicated in the previous paragraphs, discretizing the computation with respect to a Minimum Geographical Reference Unit (UMR), coinciding with a $250 \times 250 \mathrm{~m}$ size cell of a reference grid. In particular, the damage was assessed through the socalled Risk Index (RC), related to the expected number of collapsed roofs, per cell, calculated using the relation (5).

$$
R_{C}=\sum_{i=1}^{n-1} N c\left(q_{i}\right) \cdot\left(P_{i}-P_{i+1}\right)+\left(N c\left(q_{n}\right) \cdot P_{n}\right.
$$

where: $\mathrm{P}_{\mathrm{i}}=$ probability of exceeding the load level qi

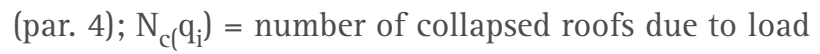
qi (estimated on the basis of the vulnerability curves of Figure 2); $\mathrm{n}=$ total number of considered load levels (note that the significant load thresholds for the calculation of the risk index are only those higher than $100 \mathrm{~kg} / \mathrm{m}^{2}$, therefore we have $\left.\mathrm{n}=25\right) ; \mathrm{P}_{\mathrm{i}}-\mathrm{P}_{\mathrm{i}+1}=$ probability that the load produced by fallout deposits is be- tween $\mathrm{q}_{\mathrm{i}}$ and $\mathrm{q}_{\mathrm{i}+1}$.

It is important to precise that the assessment of the 'risk index' does not provide a real risk analysis of ash fallout, because it does not consider the hazard of all the possible eruptive sizes (even considering the variability of winds and vents), but takes in to account the 'average' only, used as a reference in the drafting of the plan.

For example, Figure 8 represents, for the Vesuvius, the limit of the invasion area of pyroclastic flows (continuous black line), evaluated according to the indications of Gurioli et al. [2010], and the area with significant risk index (dotted red line), determined according to the equation (5).

From the overlap of the areas subject to invasion by pyroclastic flows [Vesuvius: Gurioli et al., 2010; Campi Flegrei: Lirer et al., 2001, Alberico et al., 2002; Rossano et al., 2004; Orsi et al., 2004 ; Todesco et al., 2006; Esposti Ongaro et al., 2008, 2012; Alberico et al., 2011; Bevilacqua et al., 2012] with the areas subject to substantial damage to building roofs due to fallout deposits, the red zone for Vesuvius (Figure 9) and Campi Flegrei (Figure 10) Emergency Plans were established. The yellow zones are identified as those areas outside the red zone exposed to the considered reference eruptions, to an ash load of more than $300 \mathrm{~kg} / \mathrm{m} 2$ (load capable of producing roof collapses), with a probability of surplus of 5\%. Actually, at the time of the eruption, a portion of the yellow zone only will be hit by fallout deposits, depending on the intensity and direction of the stratospheric winds. Therefore, only a portion of this area should be evacuated. During the volcanic unrest, in order to organize this second evacuation and to better manage and allocate the resources, in real time scenario analyses are necessary. These evaluations allow to evaluate the extent of the areas really exposed to damages for ash fallout, according to the real wind conditions. 


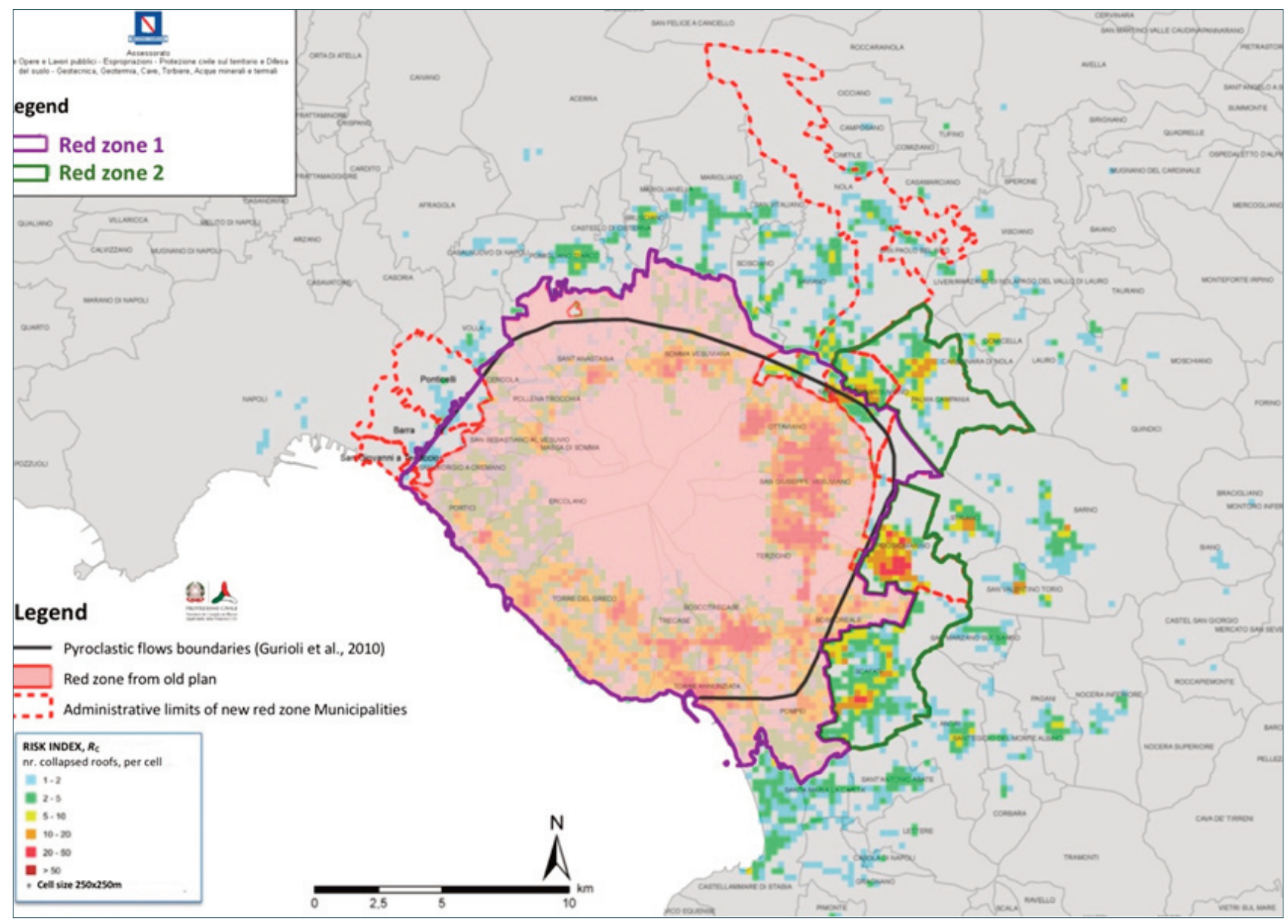

FUGURE 8. Vesuvius Emergency Plan. Pyroclastic flows boundaries (continuous black line) and area subject to a substantial number of damages due to ash fallout (dotted red line; Campania Region Resolution N. 250, 07/26/2013).

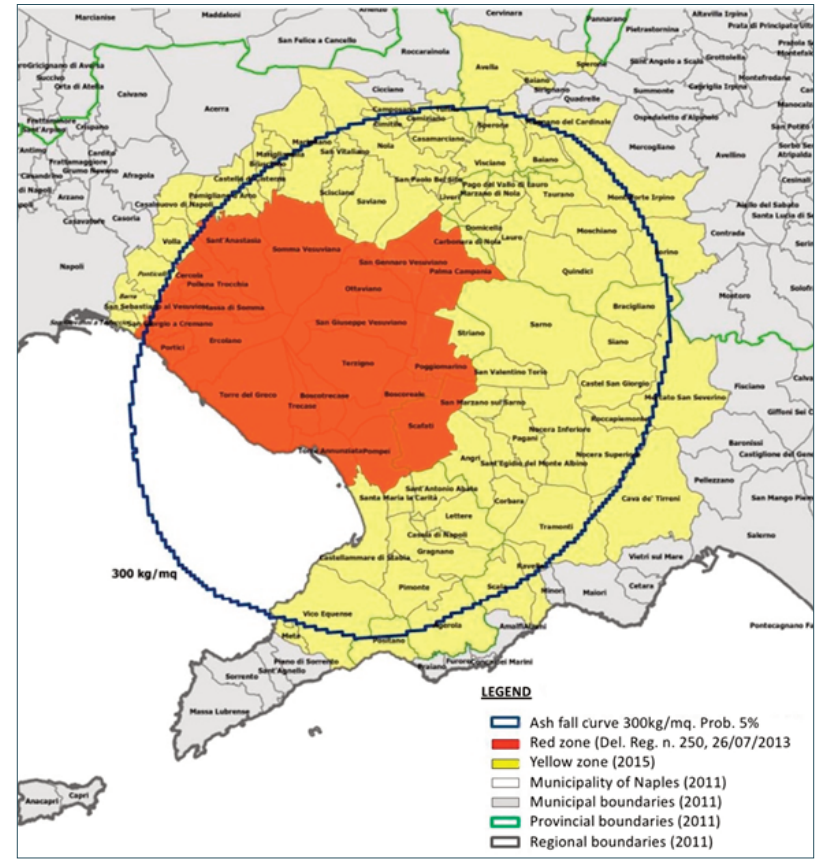

FUGURE 9. The red and yellow zones of Vesuvius Emergency Plan 2015. Blue line indicates the limit of $300 \mathrm{~kg} / \mathrm{m}^{2}$ of ash fallout load.

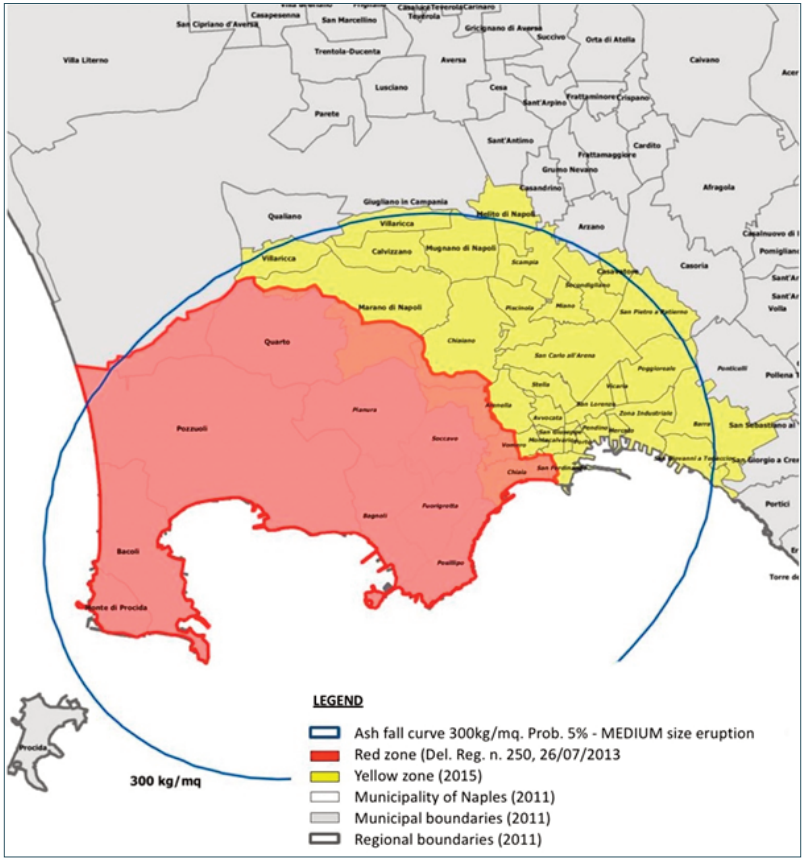

FUGURE 10. The red and yellow zones of Campi Flegrei Emergency Plan 2015. Blue line indicates the limit of $300 \mathrm{~kg} / \mathrm{m}^{2}$ of ash fallout load. 


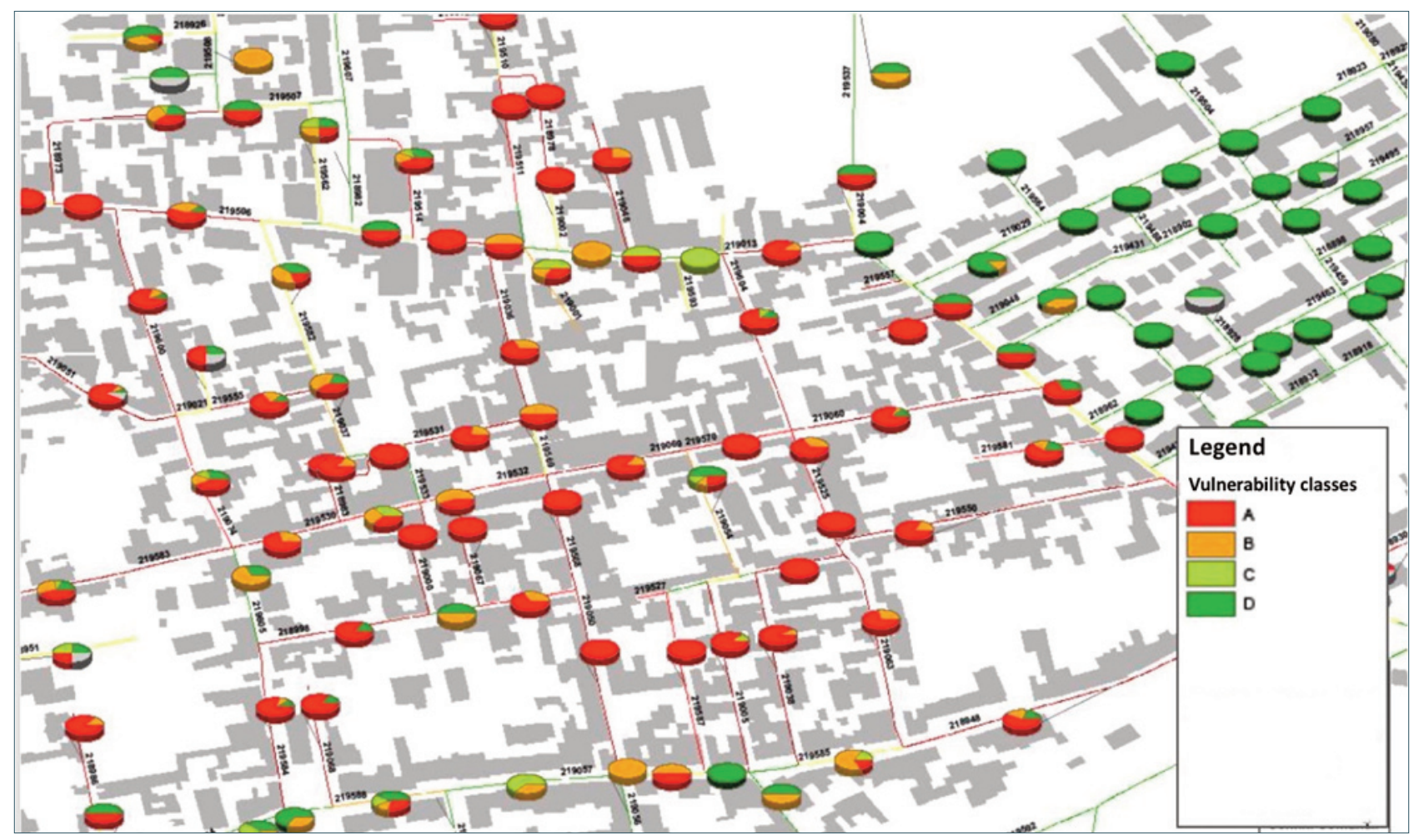

FUGURE 11. Distribution of the classes of seismic vulnerability of buildings along the road sections of Boscoreale Municipality of Vesuvius.

\section{SCENARIO ANALYSIS FOR THE CHOICE OF ROUTES TO BE USED FOR THE PRE-ERUP- TION EVACUATION}

In the Emergency plan, the choice of the roadway to be used for the evacuation of the red zone is very important. Evacuation will start when the "Alarm level" for impending eruption is declared, which is linked to a significant variation of the monitored parameters (seismicity, soil deformation, composition of the gases in the fumaroles, etc.). This pre-eruption phase is usually characterized by the occurrence of precursor earthquakes, which could strongly affect the practicability of the roads, due to the rubble produced by the damage suffered by facing buildings that may invade the roadway (Figure 5). In the red zone, therefore, possible collapses, even only partial, of buildings located close to the routes planned for the evacuation could cause the interruption of the routes with very serious consequences on the outflow operations from the area. Therefore, it reasonable to assume that the probability of interrupting a stretch of road is strongly correlated with the seismic vulnerability of the buildings facing it. For Vesuvius and Campi Flegrei, in order to identify any criticality of the escape route graph identified for the evacuation, the impact induced by a seismic event with VIII (EMS ‘98) macroseismic intensity was as- sessed. It is important to note that the seismic intensity has been assumed constant over the entire area of the road graph, disregarding the position of the epicenter of the pre-eruptive seismic events in order to give a uniform input evaluation. The graph of the escape routes has been divided into links (link = road section between two road intersections). For each i-th link, the probability of interruption Pi was evaluated [see relation (4)] for a given seismic intensity I, according to the expected number (Nc) of buildings affected by partial or total collapse due to the seismic action assumed. The evaluation includes all the buildings facing the road link, which are no more than $15 \mathrm{~m}$ from the road axis. In detail, the procedure adopted for estimating the probability of interruption of road sections is as follows [Zuccaro and Cacace, 2010]:

- on the graphs of the escape routes of the Municipalities of the Vesuvian and Flegrean area, all the road sections (links) of variable dimensions, between two nodes, have been identified;

- along each link, the buildings facing the road have been identified, at a distance of less than $15 \mathrm{~m}$ from the road axis;

- for each building the class of seismic vulnerability has been determined (Figure 11);

- with reference to the assumed macroseismic intensity (VIII), the distribution of the expected damage to 


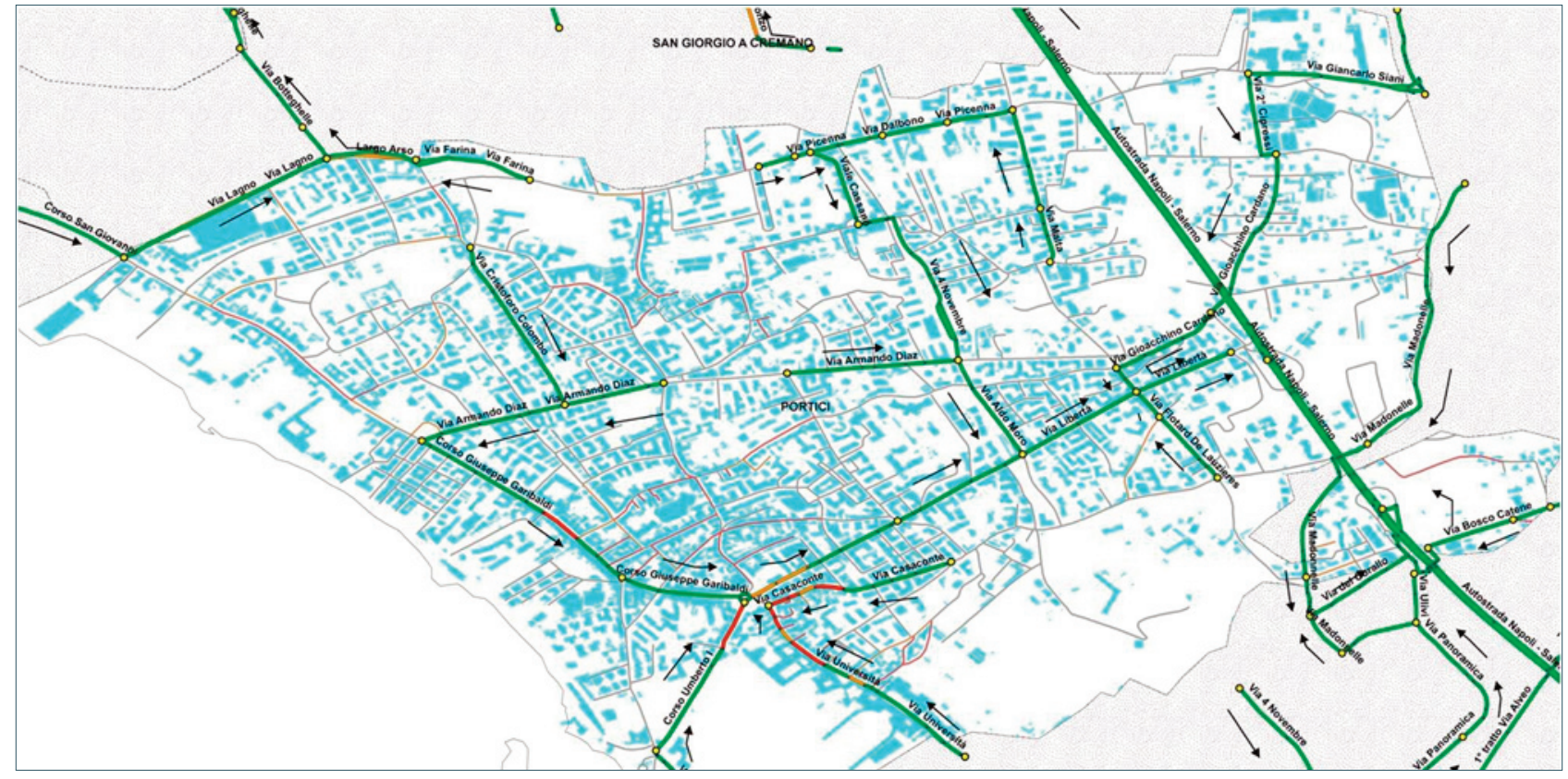

FUGURE 12. Vesuvius (Portici Municipality). In red, the road links with a probability of interruption of more than 60\% due to a precursor earthquake of intensity VIII.

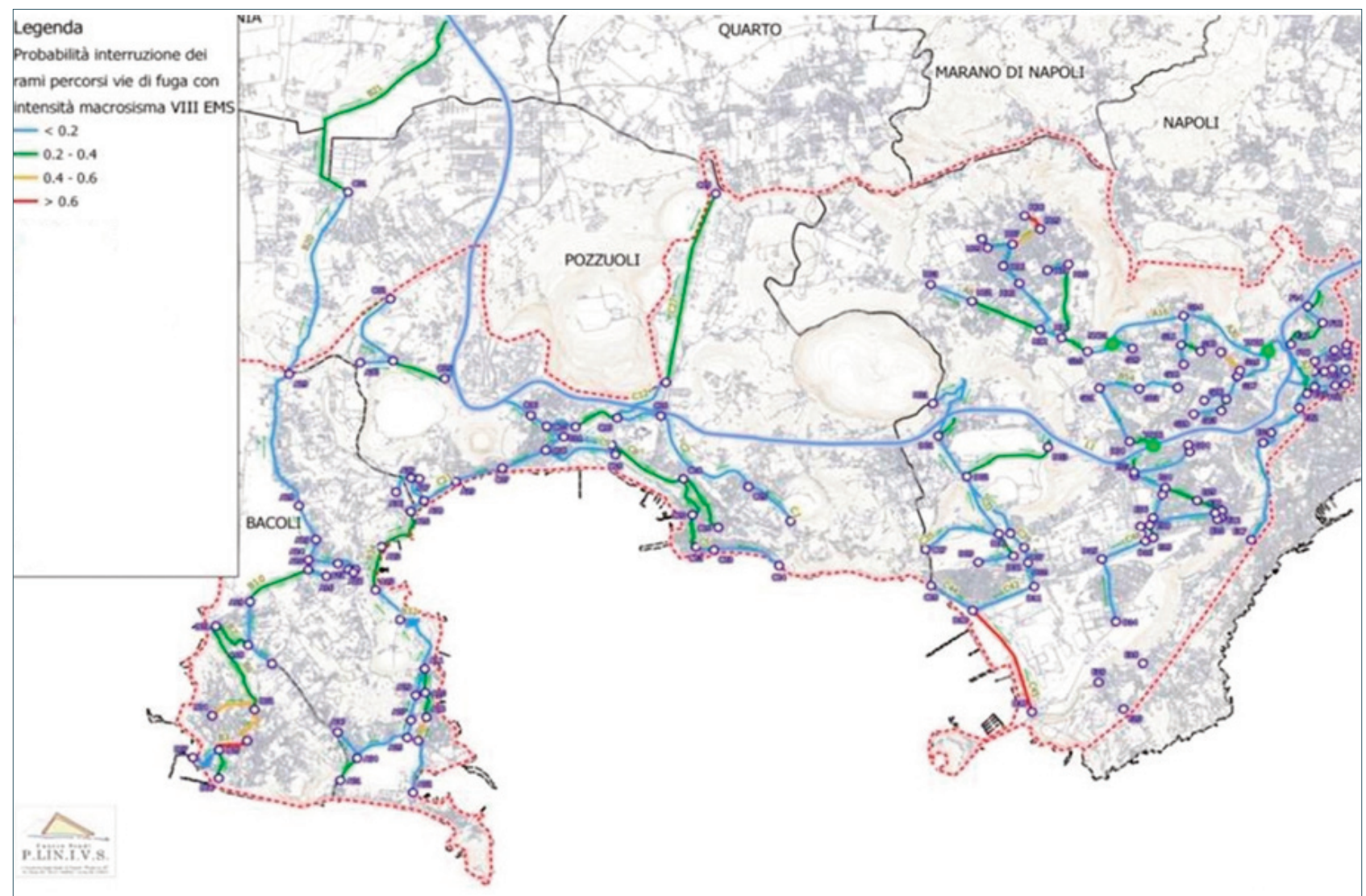

FUGURE 13. Campi Flegrei. In red, the road links with a probability of interruption of more than $60 \%$ due to a precursor earthquake of intensity VIII.

buildings along the link (through the seismic vulnerability curves of Figure 1) has been calculated, and therefore, for each link, the number of buildings affected by partial or total collapse (NC) has been estimated;

- for each of the links analyzed, the probability of interruption has been determined, through the relation (2). 
The obtained results are summarized in the maps of Figures 12 and 13, with reference to a Boscoreale $\mathrm{Mu}$ nicipality of Vesuvius and to Campi Flegrei respectively. In red, road links with a probability of interruption of more than $60 \%$ are shown. The severity of the expected damages suggests the need for an in-depth investigation of the seismic vulnerability of the buildings along the routes, and possibly the planning of seismic consolidation interventions or the search for alternative routes, in order to optimize the practicability of the routes to be used for evacuation of the red zone during a volcanic emergency. These data, however, can also be used to assess the damage produced in the red zone by the preeruption earthquakes, in order to optimize the relief management. A very serious problem arises from these results: in the very delicate phase shortly preceding the issue of the alarm for impending eruption, because of the high seismic vulnerability of many buildings in the red zone of both volcanos, civil protection might have to face a seismic emergency with severe causalities, whose management is furtherly obstructed by the impracticability of many road sections.

\section{CONCLUSIONS}

Emergency planning in urban areas exposed to volcanic risk is closely linked to the statistical assessment of the damage caused by the expected volcanic phenomena. In this paper, some approaches are illustrated for the evaluation of impact scenarios in the Vesuvius and Campi Flegrei territory related to a reference volcanic event. Results are useful to draw up specific Emergency Plans which are an important tool to mitigate volcanic risk, establishing the actions to be taken in case of crisis, including the evacuation of the population from areas exposed to serious danger.

Impact scenarios can be also used as a guide tool to reduce exposure, for example providing a better territorial planning, controlling the realization of new buildings in exposed areas and/or reducing the volcanic vulnerability of exposed elements, in particular the seismic vulnerability of buildings facing the escape roads.

In particular, the use of risk and scenario analyses is highlighted. The former is useful for evaluating intervention strategies, for example the evacuation priorities. The latter, through the identification of the extension of the exposed area and the assessment of the territorial impact, is useful for the quantification of the resources needed for carrying out an efficient operational emergency intervention. The assessment of the consequences of a volcanic eruption on the invested areas includes the complexity, not illustrated in this article, related to the multiplicity of phenomena potentially triggered by an eruption (earthquake, pyroclastic flows, ash fallout, tsunamis, landslides, lahars, lava, flows, etc.) that, being able to invest the same element at risk, require the articulated and uncertain evaluation of the progressive cumulative and final damage. The overall assessment of volcanic eruption damage includes issues, such as the estimate of time-dependent vulnerability [Zuccaro and De Gregorio, 2013], or of the chain effects [Dihé et al., 2013; Molarius et al., 2014; Zuccaro et al., 2018] and the evaluation of direct and indirect economic damage [Zuccaro et al., 2013], which are outside the scope of this paper.

\section{REFERENCES}

Alberico, I., L. Lirer, P. Petrosino and R. Scandone (2002). A methodology for the evaluation of long term volcanic risk from pyroclastic flows in Campi Flegrei (Italy), J. Volcanol. Geotherm. Res. 116, 63- 78.

Alberico, I., P. Petrosino and L. Lirer (2011). Volcanic hazard and risk assessment in a multi-source volcanic area: the example of Napoli city (Southern Italy), Nat. Hazards Earth Syst. Sci., 11, 1057-1070.

Baxter, P.J. (1990). Medical effects of volcanic eruptions; I-main causes of doneath and injury, Bull. Volcanol., 52; 7:532-544.

Baxter, P.J., A. Neri and M. Todesco (1998). Physical modelling and human survival in pyroclastic flows", Natural Hazards, 17:165-176.

Baxter, P., R. Boyd, P. Cole, A. Neri, R. Spence and G. Zuccaro (2005). The impacts of pyroclastic surges on buildings at the eruption of the Soufriere Hills Volcano, Montserrat, Bulletin of Volcanology, 67, 292-313.

Baxter, P.J., W. Aspinall, A. Neri, G. Zuccaro, R.S.J. Spence, R. Cioni and G. Woo (2008). Emergency planning and mitigation at Vesuvius: A new evidence-based approach, Journal of Volcanology and Geothermal Research, 178, 3, 454-473, doi: 10.1016/j.jvolgeores.2008.08.015 (1).

Bevilacqua, A., C. Fourmentraux, A. Bertagnini, M. Bisson, T. Esposti Ongaro, F. Flandoli, R. Isaia, A. Neri 
and M. Rosi (2012). Mapping pyroclastic flow hazard in a caldera setting: application to Campi Flegrei caldera, EGU General Assembly 2012, Vienna, Austria.

Bevilacqua, A., R. Isaia, A. Neri, S. Vitale, W.P. Aspinall, M. Bisson, F. Flandoli, P.J. Baxter, A. Bertagnini, T. Esposti Ongaro, E. Iannuzzi, M. Pistolesi and M. Rosi (2015). Quantifying volcanic hazard at Campi Flegrei caldera (Italy) with uncertainty assessment: I, Vent opening maps, Journal of Geophysical Research, 120, doi:10.1002/2014JB011775.

Bevilacqua A., F. Flandoli, A. Neri, R. Isaia and S. Vitale (2016). Temporal models for the episodic volcanism of Campi Flegrei caldera (Italy) with uncertainty quantification, Journal of Geophysical Research, 121, doi:10.1002/2016JB013171.

Bevilacqua A., A. Neri, M. Bisson, T. Esposti Ongaro, F. Flandoli, R. Isaia, M. Rosi and S. Vitale (2017). The effect of vent location, event scale and time forecast on pyroclastic density current hazard maps at Campi Flegrei caldera (Italy), Front. Earth Sci., 5:72, doi.org/10.3389/feart.2017.00072.

Cacace, F., G. Zuccaro, D. De Gregorio and F.L. Perelli (2018). Building Inventory at National scale by evaluation of seismic vulnerability classes distribution based on Census data analysis: BINC procedure, International journal of disaster risk reduction, p. 384-393, ISSN: 2212-4209

CAR (2013). Consultants report: Global Seismic Risk Assessment for UK Government, Cambridge Architectural Research Ltd.

Cioni, R., A. Bertagnini, R. Santacroce and D. Andronico (2008). Explosive activity and eruption scenarios at Somma-Vesuvius (Italy): towards a new classification scheme, Journal of Volcanology and Geothermal Research 178 (3), 331-346.

Cole, P., A. Neri and P.J. Baxter (2015). Pyroclastic density current hazard, Book "Encyclopedia of Volcanoes", Chief Editor H. Sigurddsson, Academic Press Publisher, Chapter 54.

Costa, A., F. Dell'Erba, M.A. Di Vito, R. Isaia, G. Macedonio, G. Orsi, and T. Pfeiffer (2009). Tephra fallout hazard assessment at the Campi Flegrei caldera (Italy), Bulletin of Volcanology, 71, 259273, doi:10.1007/s00445-008- 0220-3.

Dihé, P., R. Denzer, M. Polese, A.M. Heikkilä, D. Havlik, J. Sautter, T. Hell, S. Schlobinski and G. Zuccaro (2013). An architecture for integrated crisis management simulation, In Proceedings of the 20th
International Congress on Modelling and Simulation, Adelaide, Australia (pp. 1-6), ISBN: 9780987214331.

Esposti Ongaro T., C. Cavazzoni, G. Erbacci, A. Neri and M.V. Salvetti (2007). A parallel multiphase flow code for the 3D simulation of volcanic explosive eruptions, Parallel Computing, 33, 7-8, 541-560 doi: 10.1016/j.parco.2007.04.003

Esposti Ongaro, T., P. Marianelli, M. Todesco, A. Neri, C. Cavazzoni and G. Erbacci (2008). Mappe tematiche, geo-referenziate e digitali, delle principali azioni pericolose associate alle colate piroclastiche del Vesuvio e dei Campi Flegrei derivanti dalle nuove simulazioni 3D, prodotto 2.3.5, Progetto SPEED.

Esposti Ongaro, T., A. Neri, G. Menconi, M. de' Michieli Vitturi, P. Marianelli, C. Cavazzoni, G. Erbacci and P.J. Baxter (2008). Transient 3D numerical simulations of column collapse and pyroclastic density current scenarios at Vesuvius, 178, 3, 378-396, Journal of Volcanology and Geothermal Research, doi: 10.1016/j.jvolgeores.2008.06.036.

Esposti Ongaro, T., A. Neri and M. Todesco (2012). Assessing pyroclastic density current dynamics and hazard of Plinian events at Campi Flegrei (Italy) by using 3D numerical simulations, EGU General Assembly 2012, Vienna, Austria.

Fournier d'Albe, E.M. (1979). Objectives of Volcanic Monitoring and Prediction, Journ. Geol. Soc. Lond, 136, 321-326.

Gurioli, L., R. Sulpizio, R. Cioni, A. Sbrana, R. Santacroce, W. Luperini and D. Andronico (2010). Pyroclastic flow hazard assessment at Somma -Vesuvius based on the geological record, Bull Volcanol, 72:1021-1038, Springer-Verlag.

Grünthal, G. (1998). European Macroseismic Scale 1998 (EMS, 98).

Lirer, L., P. Petrosino and I. Alberico (2001). Hazard assessment at volcanic fields: the Campi Flegrei case history, J. Volcanol. Geotherm. Res., 112, 53-74.

Macedonio, G., A. Costa, S. Scollo and A. Neri (2016). Effects of eruption source parameter variation and meteorological dataset on tephra fallout hazard assessment: example from Vesuvius (Italy), Journal of Applied Volcanology, 5:5, doi:10.1186/s13617016-0045-2.

Mastrolorenzo, G., L. Pappalardo, C. Troise, A. Panizza and G. De Natale (2008). Probabilistic tephra hazard maps for the neapolitan area: Quantitaive vol- 
canological study of Campi Flegrei eruptions, J. Geophys. Res., doi:10.1029/2007JB004954.

Mavrouli, O., S. Fotopoulou, K. Pitilakis, G. Zuccaro, J. Corominas, A. Santo, F. Cacace, D. De Gregorio, G. Di Crescenzo, E. Foerster and T. Ulrich (2014). Vulnerability assessment for reinforced concrete buildings exposed to landslides, Bulletin of engineering geology and the environment, vol. 73, p. 265-289, ISSN: 1435-9529, doi: 10.1007/s10064014-0573-0.

Michel, C. and C. Sira (2012). Fiche Analyse de Vulnerabilite Batimentaire (V 8.0), BCSF France.

Molarius, R., P. Tuomaala, K. Piira, M. Räikkönen, C. Aubrecht, M. Polese, G. Zuccaro, K. Pilli-Sihvola and K. Rannat (2014). Systemic Vulnerability and Resilience Analysis of Electric and Transport Network Failure in Cases of Extreme Winter Storms, In: Proceedings of ASCE-ICVRAM-ISUMA 2014. Liverpool (UK), 13-16 July 2014.

Neri, A., T. Esposti Ongaro, G. Menconi, M. de’ Michieli Vitturi, C. Cavazzoni, G. Erbacci and P.J. Baxter (2007). 4D Simulation of esplosive eruption dynamics at Vesuvius, Geophysical Research Letters, 34, doi: 10.1029/2006GL028597.

Neri, A., W.P. Aspinall, R. Cioni, A. Bertagnini, P.J. Baxter, G. Zuccaro, D. Andronico, S. Barsotti, P.D. Cole, T. Esposti Ongaro, T.K. Hincks, G. Macedonio, P. Papale, M. Rosi, R. Santacroce and G. Woo (2008). Developing an Event Tree for Probabilistic Hazard and Risk Assessment at Vesuvius, Journal of Volcanology and Geothermal Research, 178, 3, 397-415, doi: 10.1016/j.jvolgeores.2008.05.014.

Neri, A., T. Esposti Ongaro, B. Voight and C. Widiwijayanti (2014). Pyroclastic density current hazards and risk, Book "Volcanic Hazards, Risks and Disasters", Editors P. Papale, J. Eichelberger, S. Loughlin, S. Nakada and H. Yepes, Elsevier Publisher, 109-140.

Neri, A., A. Bevilacqua, T. Esposti Ongaro, R. Isaia, W.P. Aspinall, M. Bisson, F. Flandoli, P.J. Baxter, A. Bertagnini, E. Iannuzzi, S. Orsucci, M. Pistolesi, M. Rosi and S. Vitale (2015). Quantifying volcanic hazard at Campi Flegrei caldera (Italy) with uncertainty assessment: II. Pyroclastic density current invasion maps, Journal of Geophysical Research, 120, doi:10.1002/2014JB011776.

Orsi, G., M.A. Di Vito, R. Isaia, L. Civetta, M. D’Antonio and G. Vilardo (2004a). Pericolosità vulcanica della caldera dei Campi Flegrei in caso di ripresa dell'attività in tempi medi o brevi, Relazione per il Gruppo di Lavoro "Scenari e livelli di allerta" della Commissione Nazionale per l'Aggiornamento dei Piani di Emergenza dell'Area Vesuviana e Flegrea per il Rischio Vulcanico, 40 pp.

Orsi, G., M.A Di Vito and R. Isaia (2004b). Volcanic hazard assessment at the restless Campi Flegrei caldera, Bull. Volcanol., 66, 514-530.

Orsi, G., M.A. Di Vito, J. Selva and W. Marzocchi (2009). Long-term forecast of eruptive style and size at Campi Flegrei caldera (Italy), Earth Planet. Sci. Lett., 287, 265-276.

Petrazzuoli S.M. and G. Zuccaro (2004). Structural resistance of reinforced concrete buildings under pyroclastic flows: a study of the Vesuvian area, J. Volcanol. Geoth. Res. 133:1-15, 2004.

Rossano, S., G. Mastrolorenzo and G. De Natale (2004). Numerical simulation of pyroclastic density currents on Campi Flegrei topography: a tool for statistical hazard estimation, J. Volcanol. Geotherm. Res., 132, 1-14.

Selva, J., A. Costa, W. Marzocchi and L. Sandri (2010). BET VH: Exploring the influence of natural uncertainties on long-term hazard from tephra fallout at Campi Flegrei (Italy), Bulletin of Volcanology, 72(6), 717-733, doi:10.1007/s00445010-0358-7.

Selva, J., G. Orsi, M.A. Di Vito, W. Marzocchi and L. Sandri (2011). Probability hazard map for future vent opening at the Campi Flegrei caldera (Italy), Bull. Volcanol., DOI 10.1007/s00445-011-0528-2.

Selva, J., A. Costa, L. Sandri, G. Macedonio and W. Marzocchi (2014). Probabilistic short- term volcanic hazard in phases of unrest: A case study for tephra fallout

Journal of Geophysical Research, Solid Earth 119 (12), 8805-8826.

Spence, R.J.S., P.J. Baxter and G. Zuccaro (2004a). Building vulnerability and human casualty estimation for a pyroclastic flow: a model and its application to Vesuvius, J. Volcanol. Geoth. Res. 133 (2004):321-343.

Spence, R., G. Zuccaro, S. Petrazzuoli and P.J. Baxter (2004b). The resistance of buildings to pyroclastic flows: theoretical and experimental studies in relation to Vesuvius, ASCE Nat Hazards Rev 5:4850. ISSN: 1527-6988.

Spence, R., I. Kelman, P.J. Baxter, G. Zuccaro and S. Petrazzuoli (2005). Residential building and occu- 
pant vulnerability to tephra fall”, Nat. Hazard Earth Syst. Sc. 5:477-494.

Tadini, A., A. Bevilacqua, A. Neri, R. Cioni, W.P. Aspinall, M. Bisson, R. Isaia, F. Mazzarini, G.A. Valentine, S. Vitale, P.J. Baxter, A. Bertagnini, M. Cerminara, M. de' Michieli Vitturi, A. Di Roberto, S. Engwell, T. Esposti Ongaro, F. Flandoli and M. Pistolesi (2017). Assessing future vent opening location at the Somma-Vesuvio volcanic complex: 2. Probability maps of Somma-Vesuvio caldera with uncertainty information, Journal of Geophysical Research, 122, doi:10.1002/2016JB013860.

Todesco, M., A. Neri, T. Esposti Ongaro, P. Papale and M. Rosi (2006). Pyroclastic flow dynamics and hazard in a caldera setting: Application to Phlegrean Fields (Italy), doi:10.1029/ 2006GC001314.

Unesco (1972). Smithsonian Institution/SEAN, 1989, Global Volcanism Smithsonian Institution, Prentice Hall, New Jersey, USA.

Wilson G., T.M. Wilson, N.I. Deligne and J.W. Cole (2014). Volcanic hazard impacts to critical infrastructure: A review, Journal of Volcanology and Geoth. Research 286 (2014) 148-182.

Zuccaro, G. (2004). Final report SAVE. Project Link to the Web Page of the "Save" Project in "Atlantis". http://gndt.ingv.it/Att_scient/Prodotti_attesi_2004/Dolce_Zuccaro/Mappe/ Start2.htm. Roma.

Zuccaro, G., V. Albanese, F. Cacace, C. Mercuri and F. Papa (2008a). Seismic Vulnerability Evaluations within the Structural and Functional Survey Activities of the COM bases in Italy, AIP Conference.

Zuccaro, G., F. Cacace, R.J.S. Spence and P.J. Baxter (2008b). Impact of explosive eruption scenarios at Vesuvius”, J Volcanol Geoth Res 178(2008):416453.

Zuccaro, G. and F. Cacace (2010). Seismic impact scenarios in the volcanic areas in Campania. In: F.M. Mazzolani, Urban habitat construction under catastrophic events, p. 725-730, CRC Press, ISBN: 9780415606851.

Zuccaro, G., F. Cacace and D. De Gregorio (2012). Buildings inventory for seismic vulnerability assessment at National and regional scale", In: 15th World Conference on Earthquake Engineering, 15th WCEE 2012, Lisbon (Portugal), 24-28 September 2012, Paper no 2829.

Zuccaro, G. and D. De Gregorio (2013). Time and Space dependency in impact damage evaluation of a sub- Plinian eruption at Mount Vesuvius, Natural Hazard (2013) 68:1399-1423. DOI: 10.1007/s11069-013-0571-8.

Zuccaro, G., M.F. Leone, D. Del Cogliano and A. Sgroi (2013). Economic impact of explosive volcanic eruptions: A simulation-based assessment model applied to Campania region volcanoes, journal of volcanology and geothermal research, vol. 266, p. 1-15, ISSN: 0377-0273, doi: 10.1016/j.jvolgeores.2013.09.002.

Zuccaro, G., D. De Gregorio and P. Baxter (2014). Human and Structural Vulnerability to Volcanic Processes, in: P. Papale. (a cura di): J. Shroder, Volcanic Hazards, Risks and Disasters, vol. Chapter 10, p. 261-288, Elsevier, ISBN: 9780123964533.

Zuccaro, G. and F. Cacace (2015). Seismic vulnerability assessment based on typological characteristics. The first level procedure "SAVE", Soil Dynamics and Earthquake Engineering (2015), pp. 262-269 DOI information: 10.1016/j.soildyn.2014.11.003.

Zuccaro, G. and D. De Gregorio (2016). Valutazioni di impatto in aree vulcaniche: Somma- Vesuvio e Campi Flegrei, In: Lirer Lucio, (a cura di): Lirer Lucio, Il Vulcanismo Esplosivo. p. 59-76, ISBN: 979-12-200-1042-9.

Zuccaro, G., D. De Gregorio and M.F. Leone (2018). Theoretical model for cascading effects analyses, International Journal of Disaster Risk Reduction, https://doi.org/10.1016/j.ijdrr.2018.04.019 In Press, Accepted Manuscript.

CORRESPONDING AUTHOR: Giulio ZUCCARO Department of Structures for Engineering and Architecture University of Naples Federico II, Napoli, Italy email: zuccaro@unina.it

(C) 2019 the Istituto Nazionale di Geofisica e Vulcanologia. All rights reserved 